\title{
Communication styles and strategies of the meaning transfer of teachers when working with gifted children
}

\author{
Elena A. Suroedova
}

Don State Technical University, Faculty of Psychology, Pedagogy and Defectology, Department of Psychology of Education, Gagarin Square, 1, Rostov-on-Don, 344000, Russian Federation

\section{Introduction}

The problem of pedagogical communication over the past fifty years is particularly relevant. Effective communication between the teacher and students has a positive developmental impact on them. Gifted children demanded an individual approach from the teacher. The aim of the study was to study the features of communication styles and strategies of the meaning transfer of teachers when working with gifted children. The theoretical basis of the study included such ideas as the personal-semantic paradigm of education (A. G. Asmolov, I. V. Abakumova), psychology of a joint thinking activity (A. K. Belousova, M. A. Westvirgina, D. F. Dautov), ideas about the phenomenon of transfer of meaning, translation of meaning (A. K. Belousova, E. J. Artemieva, L. C. Kagermazova, E. A. Suroedova, etc.), stylistic approach (A. Adler, F. Holtzman, G. Schlesinger, Kagan, J. Sternberg, George. Bruner, A. K. Belousova, M. A. Cold, A. Rean and others).

\section{Materials and Methods}

The study involved teachers, women aged 25-45 years, educators and teachers. The following methods were used in the study: questionnaires, interviews, observation and methods of mathematical statistics. The study used the following research methods: "Methods for diagnostics of teacher communication styles" (N. P. Fetiskin); questionnaire "evaluation of the effectiveness of the style of pedagogical communication of teacher with children" (Y. Vonkova); methodology of "Strategies for the meaning transfer " (E. A. Suroedova).

\section{Results}

The teachers teaching in lyceum for exceptional children, the center for exceptional children at DGTU, the Dar center for musically exceptional children participated in a research. And also teachers of correctional school of Rostov-on-Don.

The results of the study allowed us to establish that teachers who deal with gifted children prefer active and democratic communication styles. In communication with children who have a high level of abilities and creative endowments teachers prefer constantly is in dialogue with trainees. At them dominates major positive mood. In work with children they encourage an initiative, feel changes in a condition of the child, easily grab to the loudspeaker in psychological climate of collective and flexibly reacts to them. During the occupations with exceptional children at teachers the style of friendly interaction with preservation of a role distance prevails. Arising educational, organizational, ethical, etc. problems are creatively solved by joint efforts. Average values by Fetiskin's technique showed that during the work with exceptional children the indicator "Model of active interaction" 15.8 points that more than $80 \%$ is dominating. During the work with children at whom speech or behavioural violations at tutors more expressed are observed "The model of the differentiated attention" (6.8 points), "Hyper reflexive model" (6.2 points), "Model of nonflexible reaction" of 5.9 points are.
The results of the study allowed us to establish that teachers who deal with gifted children prefer active $\left(U=60\right.$, at $p=0.01$, where $\left.n_{1}=12, n_{2}=20\right)$ and democratic $\left(U=58\right.$, at $p=0.008$, where $\left.n_{1}=12, n_{2}=20\right)$ communication styles.

"Effective styles of communication" allowed to reveal significant differences between teachers in orientation on effective and productive interaction with children. The teachers who are engaged with exceptional children considerably differ in democratic character and efficiency of communication with pupils $\left(U=56\right.$, at $p=0.01$ where $\left.n_{1}=12, n_{2}=20\right)$.

Significant differences in the strategy of a smysloperedacha at the teachers working with exceptional children and at correctional school are revealed. For the teachers working with exceptional children more corresponds cognitive dominating $\left(U=63\right.$, at $p=0.05$ where $\left.n_{1}=12, n_{2}=20\right)$ and active $(U=60$, at $p=0.05$ where $\left.n_{1}=12, n_{2}=20\right)$ the strategy of a smysloperedacha. These data say that they are in contact with pupils, teachers show emotionality, openness. Teachers with the active strategy of a smysloperedacha in educational process try intelligibly, distinctly and clear to open the maintenance of a subject, using at the same time emotional nonverbal levers. Teachers with kognitivno the dominating strategy pay attention to the speech, words. They are methodical and constant. Their speech. On the one hand contains many terms and concepts, and on the other hand these teachers clear and logically convey information to the pupils. In group of teachers of correctional school prevails uravnoveshannny $\left(U=66\right.$, at $p=0.05$ where $\left.n_{1}=12, n_{2}=20\right)$ or the emotional strategy of a smysloperedacha $\left(U=68\right.$, at $p=0.05$ where $\left.n_{1}=12, n_{2}=20\right)$. These data say that some teachers are excessively emotional that leads to failures and the conflicts. Other part of teachers does not differ in emotionality, but also they show speech forms of influence seldom.

The results of research on the effectiveness of interaction and strategies of sense transfer are presented in Figure 1.

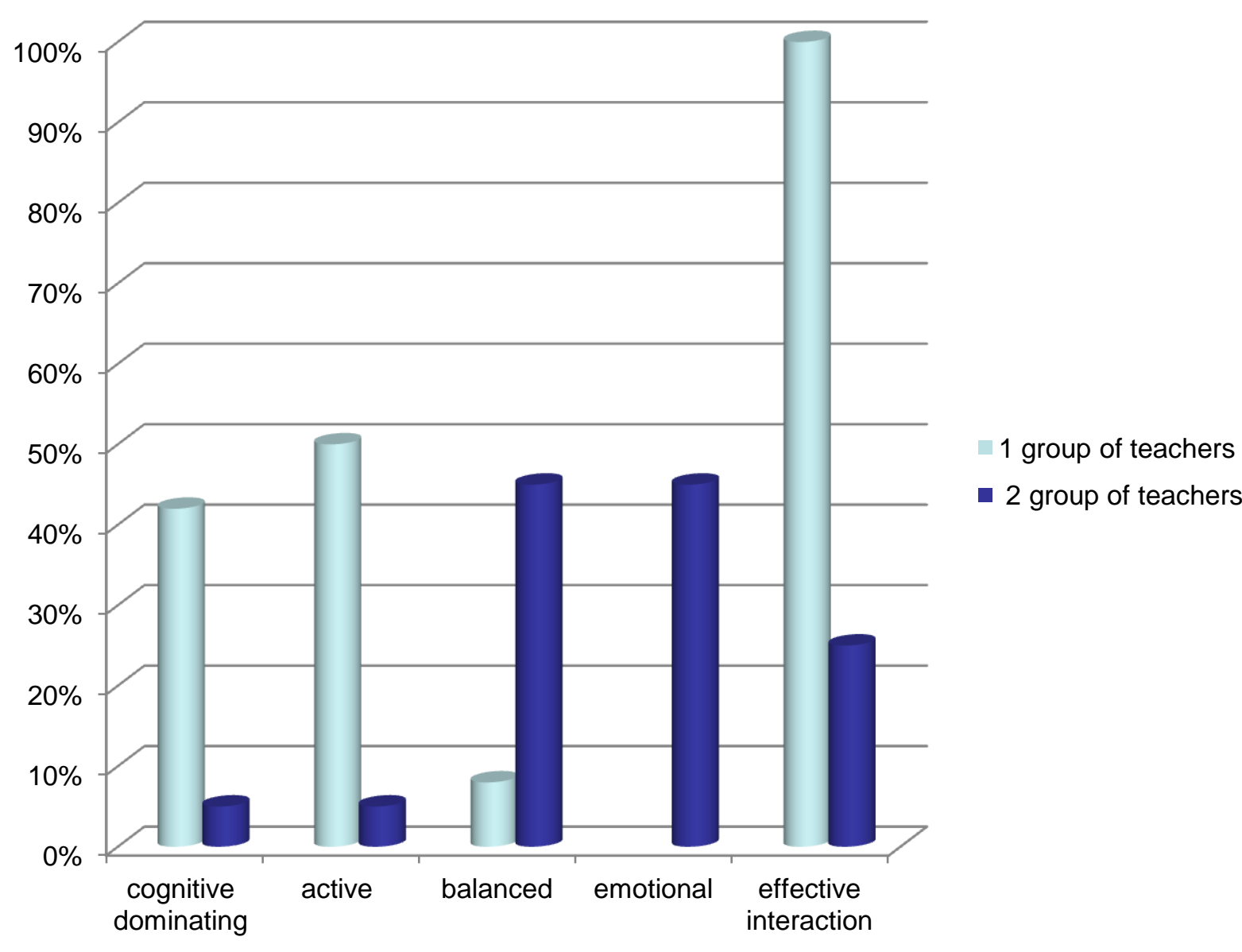

Figure 1 Results of a research of efficiency of interaction and strategy of a smysloperedacha of teachers 